\title{
Correction to: Biological sex classification with structural MRI data shows increased misclassification in transgender women
}

Claas Flint (D), Katharina Förster, Sophie A. Koser, Carsten Konrad, Pienie Zwitserlood, Klaus Berger, Marco Hermesdorf, Tilo Kircher, Igor Nenadic, Axel Krug, Bernhard T. Baune, Katharina Dohm, Ronny Redlich, Nils Opel, Volker Arolt, Tim Hahn, Xiaoyi Jiang, Udo Dannlowski and Dominik Grotegerd

(c) The Author(s) 2021

Neuropsychopharmacology (2022) 47:611; https://doi.org/10.1038/s41386-021-01203-2

Correction to: Neuropsychopharmacology https://doi.org/10.1038/ s41386-020-0666-3, published online 9 April 2020

The article "Biological sex classification with structural MRI data shows increased misclassification in transgender women", written by Claas Flint, Katharina Förster, Sophie A. Koser, Carsten Konrad, Pienie Zwitserlood, Klaus Berger, Marco Hermesdorf, Tilo Kircher, Igor Nenadic, Axel Krug, Bernhard T. Baune, Katharina Dohm, Ronny Redlich, Nils Opel, Volker Arolt, Tim Hahn, Xiaoyi Jiang, Udo Dannlowski and Dominik Grotegerd, was originally published Online First without Open Access. After publication in volume 45, issue 10, page 1758-1765 the author decided to opt for Open Choice and to make the article an Open Access publication. Therefore, the copyright of the article has been changed to $\odot$ The Author(s) 2020 and the article is forthwith distributed under the terms of the Creative Commons Attribution 4.0 International License, which permits use, sharing, adaptation, distribution and reproduction in any medium or format, as long as you give appropriate credit to the original author(s) and the source, provide a link to the Creative Commons licence, and indicate if changes were made.

The images or other third party material in this article are included in the article's Creative Commons licence, unless indicated otherwise in a credit line to the material. If material is not included in the article's Creative Commons licence and your intended use is not permitted by statutory regulation or exceeds the permitted use, you will need to obtain permission directly from the copyright holder.

To view a copy of this licence, visit http://creativecommons.org/ licenses/by/4.0\%.

The original article has been corrected.

\begin{abstract}
(c) (i) Open Access This article is licensed under a Creative Commons By Attribution 4.0 International License, which permits use, sharing, adaptation, distribution and reproduction in any medium or format, as long as you give appropriate credit to the original author(s) and the source, provide a link to the Creative Commons license, and indicate if changes were made. The images or other third party material in this article are included in the article's Creative Commons license, unless indicated otherwise in a credit line to the material. If material is not included in the article's Creative Commons license and your intended use is not permitted by statutory regulation or exceeds the permitted use, you will need to obtain permission directly from the copyright holder. To view a copy of this license, visit http://creativecommons. org/licenses/by/4.0/.
\end{abstract}

(c) The Author(s) 2021 